\title{
The Pedagogical Encouragement of Self-Regulation Applying PMM during the Activities
}

\author{
Rasa Kirliauskiené*
}

\author{
Vytautas Magnus University, Lithuania
}

\begin{abstract}
Performing for an audience is one of the most widely spread forms of social anxiety which affects many people, and fear is one of the most important causes of unsuccessful performance on stage. A university student - a future music teacher - experiences what it is like being in front of an audience and to feeling emotional strain. The aim of this research is to explore the ways which encourage students to feel better in front of an audience. Is it possible to overcome significant stage fright by having knowledge of psychological self-regulation? This article discloses the modelling of concert rehearsal tasks during individual lessons applying the personal meaning method (PMM): creating favourable preconditions to optimize the state of mind while on stage; strengthening the artistic suggestion of public performance of future teachers; positively influencing the learning motivation of students. Observation helped to analyze more deeply the behaviour of students and their activity in the process of training, comparing these dimensions with respective changes during public performances. PMM training verifying case method of analysis in the context of possibilities revealed the conditions of future music teachers' regulation of emotions while on stage, ways and the peculiarities of pedagogical encouragement.
\end{abstract}

Keywords: pedagogical encouragement, self-regulation, PMM

\section{Introduction}

Kirliauskiene (2017) states that the concept of self-regulation is disclosed through ability to relax, positive attitude and ability to control one's own thought. Self-regulation is necessary while performing the teaching activities: conducting lessons, singing, playing, conducting, etc. The essence of self-regulation lies in the ability to relax, have a positive attitude and controlling one's own thoughts, while if there is no self-regulation or it is forgotten, then suffers the quality of activities. Ways of self-regulation are based on breathing exercises, positive self-suggestion, being alone and focusing and encouraging self-confidence. Breathing exercises not only help to relax, but also direct the thoughts away from negative feelings, while concentrating on the performance of exercises and focusing on that activity. Positive controlling of your own thoughts is one of the ways of selfregulation enabling to help oneself before the performance, when negative thoughts about the future performance are overwhelming.

According Ford (2013), music and acting students give contrasting accounts of preparation, audience and performance, and that concepts of performance inform pedagogical practices, preparation habits and how students conceptualise their relationship with the audience. Leon-Guerrero (2008) analysed the capabilities of self-regulation and states that examination of the concurrent verbal report and music practice data revealed that repetition was referred to or used more frequently than other strategies. Individual, social and situational factors might play an important role on the experience of anxiety during musical performances (Castiglione, Rampullo, Cardullo, 2018). In Marijan (2017) opinion, self-regulation is formed through interaction with the environment, thus self-learning, self-analysis, self-judgment, self-instruction, and self-monitoring are the main functions in self-regulatory structure. Co-regulation is needed, and helps self-regulation to be activated and monitored.

Ersozlu et al (2017) investigated which self-regulated study strategies (self-regulated learning planning, selfregulated learning monitoring, and self-regulated learning evaluation) and predictor variables (grade level, gender, and grade point average in theoretical courses) are the best predictors of performance success in 
instrumental performance courses. In contrast to the literature (according Ersozlu et al, 2017), they found that self-report (evaluation) strategies had negative relationship with performance success in instrumental courses. This was a surprising finding because it was expected that student evaluations of their studying strategies in both theoretical and instrumental courses would have a positive effect on their IPS (instrumental performance success). Ning \& Downing (2012) disclosed that self-regulation and motivation fully mediated the learning experience - academic performance relation. In addition, hierarchical regression analysis also showed that both self-regulation and motivation had small moderating effects on the link between learning experience and academic performance. That is, the association between learning experience and cumulative GPA was stronger for students with lower levels of self-regulation and motivation.

Scientists work in different self-regulatory contexts: Bruin (2018), Miksza et al (2018), Ritchie \& Kearney (2018), Kirliauskienè (2018), Saarikallio et al (2017), Kramarski \& Kohen (2017), Hewitt (2015), Miksza \& Tan (2015), Ritchie \& Williamon (2013), Ramdass \& Bembenutty (2012). Researching different aspects of selfregulation is relevant to researchers all around the world. However, research that would reveal the techniques used to help improve one's well-being while on stage is not abundant, therefore the problem of this research is relevant. The aim of this research is to explore the ways which encourage students to feel better in front of the audience. Is it possible to overcome high emotional strain stage fright having knowledge of psychological selfregulation?

\section{Methods of the research}

Methods of research and sample: analysis of scientific literature sources, observation, interview, case study. Qualitative research data are described applying content analysis. The research was carried out in $2017-2018$. Forty-three future music teachers (second-year bachelor's degree students of music pedagogy and first-year master's degree students of music education) from Lithuanian University of Educational Sciences participated in this study. The study was carried out in two stages: in the first stage, research objectives and criteria relevant to the aim were determined. Observation was carried out, during which the activities of future music teachers playing the piano, conducting and singing solo were selected. The criteria that were anticipated were observed when performing in an assembly hall with the participation of an audience. After setting the criteria and their level, pedagogical encouragement was carried out, applying the PMM (personal meaning method) in activities to achieve a higher level of self-regulation by choosing qualitative case studies (twelve students were selected). After eight months of intensive application of the personal meaning method (working with students), the final stage of the study was performed, during which the level of self-regulation was determined after systematic work in class and on stage. The same criteria which were originally set were observed again, and interviews with the same subjects were performed after their performances on stage. Qualitative research data are described applying content analysis. The semi-structured (oral) interview was employed.

\section{Results and discussion}

The main criteria related to the manifestation of self-regulation were distinguished. 5 levels were set: 1 - lowest level, 5 - highest level, assessing self-confidence, experiencing artistic emotions, relaxation, spiritual satisfaction and positive self-suggestion and vice versa, assessing stage anxiety: 5 - strong anxiety, 1 - minimal anxiety. Table 1 presents data reflecting the first phase of the study, during which student performance was assessed. 
Table 1 The level of self-regulation during performance

\begin{tabular}{|c|c|c|c|c|c|}
\hline Statements & & & Leve & & \\
\hline & 1 & 2 & 3 & 4 & 5 \\
\hline Self-confidence & $\mathrm{x}$ & & & & \\
\hline $\begin{array}{l}\text { Experiencing artistic } \\
\text { emotions }\end{array}$ & & $\mathrm{x}$ & & & \\
\hline Relaxation & & $\mathrm{x}$ & & & \\
\hline Spiritual satisfaction & & $\mathrm{x}$ & & & \\
\hline $\begin{array}{l}\text { Positive } \\
\text { self-suggestion }\end{array}$ & $\mathrm{x}$ & & & & \\
\hline $\begin{array}{l}\text { Stage } \\
\text { anxiety }\end{array}$ & & & & & $\mathrm{x}$ \\
\hline
\end{tabular}

Table 1 presents an analysis of the distinguished criteria, which allows us to say that at the initial stage, the students did not have self-confidence during the various observed activities, which meant they could only relax minimally, were unable to experience artistic emotions, focused on performing correctly, were afraid of making any mistakes, thinking that it was crucial for them not to get flustered, because if they were to forget the notes, they would not be able to remember what they were supposed to play next. They did not feel any sort of spiritual satisfaction, they only wanted to finish their performance as soon as possible. Observing them, it was evident that they were very nervous - this was also obvious from the way their legs were shaking, their pale faces, etc. The students themselves affirmed having felt tremendous stage fright and claimed that if they could, they would not go back on stage, because it was not a place where they felt good. They did not have time to think about positive self-suggestion, their minds were only on continuing to play and avoiding making mistakes. The results are further confirmed by the data received during the interview (see Table 2).

Table 2 The manifestation of self-regulation: students' point of view

\begin{tabular}{|c|c|c|}
\hline Category & Subcategory & Proving statements \\
\hline \multirow[t]{6}{*}{ Factors } & Self-confidence & $\begin{array}{l}\text { "I understand that I must be confident but I just can't } \\
\text { be. I constantly struggle with it }<\ldots . \text { ". }\end{array}$ \\
\hline & $\begin{array}{l}\text { Experiencing artistic } \\
\text { emotions }\end{array}$ & $\begin{array}{l}\text { "<...> of course, I like the song that I was singing, } \\
\text { but I had difficulties controlling my breath and that } \\
\text { was the only thing I could focus on - I was afraid my } \\
\text { lack of professionalism would show". }\end{array}$ \\
\hline & Relaxation & $\begin{array}{l}\text { "I wish I could play the same way I do in class, when } \\
\text { I can be by myself, relax and just play, but I can't do } \\
\text { that yet }<\ldots>\text { ". }\end{array}$ \\
\hline & Spiritual satisfaction & $\begin{array}{l}\text { "I don't know how to acquire the ability to perform } \\
\text { without being nervous, feeling that my audience and } \\
\text { myself enjoy my music }<\ldots>\text { ". }\end{array}$ \\
\hline & $\begin{array}{l}\text { Positive } \\
\text { self-suggestion }\end{array}$ & $\begin{array}{l}\text { "I don't pay much attention to that, thinking that } \\
\text { perfecting my technique would solve any issues". }\end{array}$ \\
\hline & Stage anxiety & $\begin{array}{l}\text { "I get very nervous because my breathing gets } \\
\text { unevem when I sing, my legs shake, my heart beats } \\
\text { very fast, not to mention sweaty palms when I play - } \\
\text { all of it really unsettles me }<\ldots \text {.. }\end{array}$ \\
\hline
\end{tabular}


One of the objectives of this research was to disclose the pedagogical encouragement possibilities of selfregulation during the activities. PMM (personal meaning method) was chosen as the main source of encouraging self-regulation, the definition of which is presented in more detail below.

Application of PMM (personal meaning method) to promote self-regulation. All the emotional feelings and images created by the performer are rehearsed for a long time, they are somewhat of an integral part of the musical piece. According to Piličiauskas, with the help of the PMM (personal meaning method), the musical work (Vitkauskas et al, 2012) is made meaningful from the point of view of the artist and his emotional feel. Having mastered the musical piece, the focus is on the experiencing of certain emotions, with the goal of having the emotional and physiological condition of the performer be the same during the performance as it was memorizing the information, knowing that this is the best way to remember the information (Myers, 2000). During individual studies and lectures, the students are encouraged to create emociogenic images when making music. The performer creates a conception of the work that is verbalized and then immerses himself/herself in the creative process. The work created is a live flow of music with its own action. Every piece of work performed by the students has its own concept, i.e. it acquires subjective meaning. The justification for the concept is the artist's creative process, starting from the first look at the score. The final and complete image of the work is formed a long period of time, it gets improved not only leading up to the performance, but every time it is repeated. The image of the musical work is the fruit of the future music teachers' fantasy. A popular association is a "field" (which, by the way, divides into many interpretations: some see meadows full of multicoloured flowers, others are able to perceive a deep philosophical aspect by seeing a lone tree in a large field, others see a poppy field, etc.), often students choose associations of "sea", "desert", "forest", "jungle", "island", "space". However, in the context of the problem being investigated, teachers should not be satisfied with only the visual images: they must adjust the students' thinking towards the artistic experiences. Therefore, it is often necessary to initiate a conversation using provocative questions what feelings do you (the protagonist, the composer, etc.) experience in the field (desert, jungle, etc.)? Is it wonder, fear, longing, joy? Emphasizing the emociogenic images rather than the visual ones in this way, one can be easily convinced that the panorama (plotline) of his/her artistic experiences is incredibly impressive, encompassing a variety of emotional tones. Teachers need to allow this artistic image to be implemented through the intonations of the work, when they get two (rarely used) opportunities: to develop artistic individuality at the level of consciousness (because the artistic experience complex of each performer will be somewhat different) and to model the anti-domination of fear (because the learners will not concentrate their attention solely on technological or memory disorders). In other words, the aim is for the object of the students' memory and all their activities to be artistic experiences, and for psychomotor (technological) tasks to be the background. It can also be said that preference is given to the interpretation of the work, not (only) its performance. The emociogenic conception of one future music teacher, prepared for F. Mendelssohn's "With Longing" No. 6 (from "The Seven Character Pieces, Op 7"), can be used to illustrate this point. The student chose the plotline of a "long tree". The main lyrical melody uniting the work is associated with the tree. The performer, embodying the tree, experiences a wide gamma of feelings. The tree, growing in the field, is proud to be so tall and beautiful. It sprouted here a long time ago, so there are many different memories. In the piano dynamics, a seemingly timid, small, slender tree begins its song. Its melody is so expressive, and the colourful harmony brings along a note of anxiety because the tree grows all alone in this field. The reoccurring theme of the tree reminds us that it grew up and matured. The colourfulness and thickness of the harmony symbolizes the spiritual state of the tree, its desire for freedom, the complexity of its feelings and contradiction in the second part of the play leading to the culmination of the work. Nevertheless, the piano following the crescendo molto suggests a hint of sadness and brings our minds back to the fact that the tree has been standing there for a long time, and it will continue to be there alone, but perhaps... When playing this piece, the performer experiences a plethora of emotional undertones: those are joy, anxiety, loneliness, freedom and more. 
The more often the performer is able to identify with the "tree" when rehearsing, and feel the positive emotions merging into the feeling of loneliness, hope, etc. of the conception of the tree, the more likely it is to transfer and imprint into the performer's memory, and to play the role of the "anti-dominant of fear". The method of personal meaning acquires a forming (modeling) function of a positive state of mind when performing on stage. Based on the idea that strong anxiety can be overcome because a person has the power inside of her/him to defeat it, an objective was set - to learn to use those powers and energy. The personal meaning method is a selfregulating measure of the psyche by which the individual is able to regulate his/her activity purposefully. Since the object and the subject of self-suggestion is the same, the subject can produce the sensations that he/she desires, control the processes of memory and attention, as well as emotional and somatic responses by the means of verbal instruction. Deliberately experiencing artistic emotions and creating the artistic image of the work in the cerebral cortex, a new focus of excitement is created, suppressing the emotion of fear - a bipolar antidominant of fear. It is very important that the performers' individuality, the personal meaning of their emotional experiences are also emphasized with the help of the personal meaning method. By experiencing the complex of artistic emotions, the learners are capable not only of strengthening the artistic impact on the listeners, they can also minimize negative stage tension due to the anti-dominant of fear.

Using the personal meaning method (see description above), a study was carried out to measure the main criteria (identified in the first phase of the study) related to the promotion of self-regulation. Qualitative case studies have been selected for the analysis. Table 3 shows the data reflecting the final stage of the study, during which the performance of students was evaluated. Criteria level: 1 - low; 2 - quite low; 3 - medium; 4 - high; 5 - very high.

Table 3 The level of self-regulation during a performance

\begin{tabular}{|c|c|c|c|c|c|}
\hline Statements & & & eve & & \\
\hline & 1 & 2 & 3 & 4 & 5 \\
\hline Self-confidence & & & & $\mathrm{x}$ & \\
\hline $\begin{array}{l}\text { Experiencing artistic } \\
\text { emotions }\end{array}$ & & & & & $\mathrm{x}$ \\
\hline Relaxation & & & & $\mathrm{x}$ & \\
\hline Spiritual satisfaction & & & & $\mathrm{x}$ & \\
\hline $\begin{array}{l}\text { Positive } \\
\text { self-suggestion }\end{array}$ & & & & $\mathrm{x}$ & \\
\hline Stage anxiety & & $\mathrm{x}$ & & & \\
\hline
\end{tabular}

The results in Table 3 reveal that at a later stage, the students who were observed during a variety of activities, had strong self-confidence when performing on the stage, were able to relax and experience artistic emotions. The students felt spiritual satisfaction when they were performing, and there were no signs of anxiety that would disrupt their performance. Furthermore, creative concentration and high quality music performances were observed. Listening to the performances, the listener was compelled to experience the emotions aroused by the music.

The results of the observation are confirmed by the data obtained during the interview (see Table 4). According to the students, they managed to create a safe space for themselves during the performance, which they had previously rehearsed many times individually, instilling in themselves that they were in a space where they felt safe. They tried to create the same vision and the same emotions that were the anti-dominant of fear. 
Rasa Kirliauskiene / The Pedagogical Encouragement of Self-Regulation Applying....

Table 4 The manifestation of self-regulation: students' point of view

\begin{tabular}{|c|c|c|}
\hline Category & Subcategory & Proving statements \\
\hline \multirow[t]{6}{*}{ Factors } & Self-confidence & $\begin{array}{l}\text { “< }<>\text { and my self-confidence improved, I believed } \\
\text { in myself: until I can be confident in myself, I don’t } \\
\text { even go on stage, it's not worth it, you never know } \\
\text { what to expect }<\ldots>\text { ". }\end{array}$ \\
\hline & $\begin{array}{l}\text { Experiencing artistic } \\
\text { emotions }\end{array}$ & $\begin{array}{l}\text { "I no longer dwell on what would happen if my } \\
\text { performance went wrong or something like that, I } \\
\text { focus all of my attention on performing music. I live } \\
\text { and breathe that music, and express my emotions in } \\
\text { that way }<\ldots \text {... }\end{array}$ \\
\hline & Relaxation & $\begin{array}{l}\text { "I don't think about any technical elements or my } \\
\text { breathing. I concentrate on the desire to perform as } \\
\text { expressively as possible and then I am able to relax, } \\
\text { the result on the stage is amazing". }\end{array}$ \\
\hline & Spiritual satisfaction & $\begin{array}{l}\text { "Finally, when I am on stage, I am able to experience } \\
\text { what I have been wanting for a long time: I can play } \\
\text { music, feel spiritual satisfaction, I hear good } \\
\text { feedback, people saying that I look great on stage and } \\
\text { that they enjoy listening to me }<\ldots \text {..." }\end{array}$ \\
\hline & $\begin{array}{l}\text { Positive } \\
\text { self-suggestion }\end{array}$ & $\begin{array}{l}\text { "I work a lot not only on technical improvement but } \\
\text { also on emotional engagement with the work"; }<\ldots> \\
\text { every time I play the piece, I place myself into the } \\
\text { vision of the piece that I have created, I never forget } \\
\text { to do that, therefore when I'm on stage, I appear } \\
\text { inside of this vision which I created for myself when I } \\
\text { was rehearsing alone". }\end{array}$ \\
\hline & Stage anxiety & $\begin{array}{l}\text { "I am already able to only feel natural anxiety, I no } \\
\text { longer feel fear when I perform on stage, that is such } \\
\text { a big achievement that allows me to express myself } \\
\text { creatively }<\ldots \text {..." }\end{array}$ \\
\hline
\end{tabular}

In summary, even though the subjects had different stage and musical experience, most of them felt strong anxiety before and during performance. By modelling the educational process and applying the PMM - a tool that helps to understand the personal meaning of a work and awakens creative joy and self-confidence - as well as a set of personalized pedagogical measures, self-regulation of the psychic state of the student - of a future music teacher - as a performer can be successfully encouraged.

According Ersozlu et al (2017), they found that self-report (evaluation) strategies had negative relationship with performance success in instrumental courses and it confirmed the results of this research during observation in 1 stage: it was evident that students were very nervous - this was also obvious from the way their legs were shaking, their pale faces, etc. The students themselves affirmed having felt tremendous stage fright and claimed that if they could, they would not go back on stage, because it was not a place where they felt good. By modelling the educational process and applying the PMM can be explained in the light of the Marijan (2017) opinion, co-regulation is needed, and helps self-regulation to be activated and monitored. According Ford (2013), music students give preparation habits and how they conceptualise their relationship with the audience and it can be improved by results of this research. The students felt spiritual satisfaction when they were performing, and there were no signs of anxiety that would disrupt their performance. Furthermore, creative concentration and high quality music performances were observed. Listening to the performances, the listener was compelled to experience the emotions aroused by the music. 


\section{Conclusions}

The results of the research revealed that future music teachers, objectively not being able to be of a high universal artistic level, are not self-confident, experience stage fright, i. e. they feel strong anxiety and therefore cannot naturally display their musical abilities. Thus, when interpreting musical works, they lose the potential for significant artistic impact.

Applying the case study method, the research revealed reserves for the optimization of university education for future music teachers. Using a self-regulatory model based on the personal meaning method helps the students to: increase the impact of artistic interpretation on the listeners, because the emotional rudiment of music becomes the object of performing arts, and each musical work is an aesthetic concept that reveals the students' artistic individuality; foster objective self-confidence and develop a self-educational motivation system, because experiencing the joy of success is becoming more common and more apparent in education; weaken the dominance of negative experiences and stage fright in the cerebral cortex because artistic modelling of a creative image on the basis of emociogenic associations naturally creates the desired artistic anti-dominant effect.

\section{References}

Bruin, L., R., 2018, Evolving Regulatory Processes Used by Students and Experts in the Acquiring of Improvisational Skills: A Qualitative Study. Journal of Research in Music Education, 65(4), 483-507.

Castiglione, C., Rampullo, A., Cardullo, S., 2018, Self Representations and Music Performance Anxiety: A Study With Professional and Amateur Musicians. Europe's Journal of Psychology, 14(4), 792-805.

Ersozlu, Z., N., Nietfeld, J., L., Huseynova, L., 2017, Predicting pre-service music teachers' performance success in instrumental courses using self-regulated study strategies and predictor variables. Music Education research, 19(2), 123-132.

Ford, B., 2013, Approaches to performance: A comparison of music and acting students' concepts of preparation, audience and performance. Music Performance Research, 6, 152-169.

Hewitt, M., P., 2015, Self-Efficacy, Self-Evaluation, and Music Performance of Secondary-Level Band Students. Journal of Research in Music Education, 63(3), 298-313.

Kirliauskienè, R., 2017, Self-regulation peculiarities of future music teachers. Educational Alternatives, 15, 100107.

Kirliauskienè, R., 2018, The peculiarities of self-regulation of future music teachers during the practice. Proceeding of the 4th International Conference on Education, 4, 69-78.

Kramarski, B., Kohen, Z., 2017, Promoting pre-service teachers' dual self-regulation roles as learners and as teachers: effects of generic vs. specific prompts. Metacognition Learning, 12, 157-191.

Leon-Guerrero, A., 2008, Self-regulation strategies used by student musicians during music practice. Music Education Research, 10 (1), 91-106.

Marijan, M., 2017, The Self-Regulated Learning Model and Music Education. Accelerando: Belgrade Journal of Music and Dance, 2, 6-64.

Miksza, P., Blackwell, J., Roseth, N., E., 2018, Self-Regulated Music Practice: Microanalysis as a Data Collection Technique and Inspiration for Pedagogical Intervention. Journal of Research in Music Education, 66(3), 295-319.

Miksza, P.,Tan L., 2015, Predicting Collegiate Wind Players' Practice Efficiency, Flow, and Self-Efficacy for Self-Regulation: An Exploratory Study of Relationships Between Teachers' Instruction and Students' Practicing. Journal of Research in Music Education, 63(2), 162-179.

Myers, D., G., 2000, Psichologija (Kaunas: Poligrafija ir informatika).

Ning, H., K., Downing, K., 2012, Influence of student learning experience on academic performance: the mediator and moderator effects of self-regulation and motivation. British Educational Research Journal, 38(2), 219-237. 
Professional and Amateur Musicians

Ramdass, D., Bembenutty, H., 2012, Exploring Self-regulatory Behaviors during Music Practice among South Asian Indian American Instrumental Students. The International Journal of Research and Review, 9, 1-31.

Ritchie, L., Kearney, P., 2018, Adult Beginner Instrumentalists' Practice Self-Regulation, and Self-Efficacy: A Pilot Study. Journal of Education and Training Studies, 6(5), 1-9.

Ritchie, L., Williamon, A., 2013, Measuring Musical Self-Regulation: Linking Processes, Skills, and Beliefs. Journal of Education and Training Studies, 1(1), 106-117.

Saarikallio, S., Baltazar, M., Västfjäll, D., 2017, Adolescents’ musical relaxation: understanding related affective processing. Nordic journal of music therapy, 26(4), 376-389.

Self Representations and Music Performance Anxiety: A Study With

Vitkauskas R., Abramauskienė J., Barisas K., Kirliauskienė R., Palubinskienė V., 2012, Bendrasis muzikinis ugdymas Lietuvoje: raida ir kryptys: (XX-XXI a. pradžia): monografija (Vilnius: Edukologija). 